\title{
READING LITERACY, MATHEMATICAL LITERACY, AND SELF-CONFIDENCE OF JUNIOR HIGH SCHOOL STUDENTS IN SINGKAWANG
}

\author{
Nurul Husna ${ }^{1)}$, Zulfahita ${ }^{2)}$, Sri Mulyani ${ }^{3)}$, Md. Shahinoor Rahman ${ }^{4)}$ \\ ${ }^{1)}$ STKIP Singkawang, Singkawang, Indonesia \\ E-mail: nuna_husna@ymail.com \\ ${ }^{2)}$ STKIP Singkawang, Singkawang, Indonesia \\ E-mail: zulfahita@yahoo.co.id \\ ${ }^{3)}$ STKIP Singkawang, Singkawang, Indonesia \\ E-mail: srimulyani.stkip@gmail.com \\ ${ }^{4)}$ University of Chittagong, Bangladesh \\ E-mail: shahinpsy@cu.ac.bd
}

\begin{abstract}
Literacy skills are very important abilities for students and are being encouraged to do so as a necessary prerequisite for lifelong learning. Because literacy skills are abilities that can be used to empower and improve the quality of individuals, families, communities, and countries. This study aims to (1) describe students' reading literacy and mathematical literacy skills based on the level of self-confidence of students in schools accredited A and B, as well as male and female students; (2) to test the comparability of reading literacy, mathematical literacy, and self-confidence based on the level of school accreditation and gender. The research method used in this research is descriptive quantitative. The sample in this study was selected using cluster sampling. The sample consisted of two public schools accredited A and B, and two private schools accredited A and B. The instruments in this study were reading literacy questions, mathematical literacy questions, student self-confidence questionnaires, and interview guidelines. The conclusions in this research are: (1) the descriptions are: (a) For schools with A accreditation, only confident students can process gathering information, processing information, and communicating information on reading literacy, while for mathematical literacy students who are confident can carry out the process Devising Strategies for Solving Problems indicators. For schools with B accreditation, students who are confident, confident enough, and less confident have carried out all the reading literacy processes, but there are still some mistakes and not according to the concept, while for mathematical literacy, students who are confident and confident enough can carry out process indicator Devising Strategies for Solving Problems. (b) For male students and female students who are confident, confident enough, and less confident to carry out the process of gathering information, processing information, and communicating information on reading literacy but still make some mistakes and do not fit the concept. As for mathematical literacy, confident female students can carry out the Communication process and Devising Strategies for Solving Problems. (2) For the comparison test, namely: (a) There is no difference in reading literacy between students from A and B accredited schools; (b) There are differences in mathematical literacy between students from A and B accredited schools; (c) There are differences in reading literacy and mathematical literacy between male students and female students; (d) There is no level of student confidence based on school accreditation and gender.
\end{abstract}

Keywords: Reading Literacy; Mathematics Literacy; Self Confidence

\section{INTRODUCTION}

Literacy skills are very important abilities for students and are being encouraged to do so as a necessary prerequisite for lifelong learning. Because literacy skills are abilities that can 
be used to empower and improve the quality of individuals, families, communities, and countries. UNESCO (2013) stated literacy as a driver of sustainable development because it makes a major contribution to the labor market, improves the health and nutrition of children and families, reduces poverty, and expands life opportunities. Conventionally literacy is defined as the ability to read and write. But now literacy is defined more broadly, including Frankel et al. (2016) stated that literacy is a process to use reading, writing, and spoken language activities appropriately to build, integrate and criticize meaningful through interaction and involvement of various vocabulary in the context of interaction in the social environment. Frankel et al. (2016) also stated that literacy is not only about reading and writing, but has developed into four contexts of more active literacy activities, namely literacy activities in the social environment, literacy activities in the school environment. (humanities, social sciences, sciences, and mathematics) and contexts outside reading and writing activities. UNESCO also defines literacy as a set of reading, writing, and numeracy skills, and literacy is now understood as a means of identification, understanding, interpretation, creation, and communication in an increasingly digital, textmediated, information-rich, and rapidly changing world.

Literacy is divided into various types according to their scientific fields, including reading literacy and mathematical literacy. This is based on the opinion of (OECD, 1999), Ma (2008), Fleischman et al. (2010), PISA (2015), Kastberg, Chan, and Murray (2016), and She, Stacey, and Schmidt (2018) which stated that literacy is divided into three, namely reading literacy, scientific literacy, and mathematical literacy. Reading literacy is understanding, using, reflecting on, and engaging with written texts, to achieve one's goals, to develop one's knowledge and potential, and to participate in society. Meanwhile, mathematical literacy is defined as an individual's capacity to formulate, employ, and interpret mathematics in a variety of contexts. It includes reasoning mathematically and using mathematical concepts, procedures, facts, and tools to describe, explain, and predict phenomena. It assists individuals to recognize the role that mathematics plays in the world and to make the wellfounded judgments and decisions needed by constructive, engaged, and reflective citizens.

According to Wildová (2015), reading literacy needs to be owned by students because reading literacy can support students' cognitive development and good literacy can guarantee student success in the future. Delgadova (2015) also stated that one of the main academic competencies that produce knowledge for the information society today is reading literacy. Reading literacy is useful for preparing educated, creative human resources who can respond flexibly to changing times. As important as reading literacy is as a basic skill for Life Skills, and as one of the main goals of learning in schools. Meanwhile, for mathematical literacy, Y1lmazer and Masal (2014) stated that mathematical literacy can improve mathematical understanding, make strong criticism, and can support skills in their daily life and work in the future. Thus reading literacy and mathematical literacy skills need attention for all levels of education.

However, several studies show that students' reading literacy and mathematical literacy skills are still low. This is based on the results of research by Kastberg, Chan, \& Murray (2016) regarding the results of the 2015 PISA measurement for students aged 15 years, for Indonesian students $51 \%$ reach levels $1-3$, and no student reaches levels 4 and 5. As for mathematical literacy, $69 \%$ of students can reach levels 1-4 and only $1 \%$ can reach the highest level 5 . According to Shu-Hua (2017), students' ability to explore when reading textbooks, reading interdisciplinary, and the ability to read in class is quite lacking. For mathematical literacy, Hidayat, Wardono, and Rusilowati (2019) stated that $34.4 \%$ of 32 students have high mathematical literacy skills. Hayati added that the students' mathematical literacy skills are generally still low. further Asmara, Waluya, and Rochmad (2017) also stated that students with low categories are at the second level and students with high categories are at the third level of mathematical literacy skills. Thus it can be concluded that the students' reading literacy and mathematical literacy skills are low.

Self-confidence in students needs to be instilled, especially when students learn and answer questions so that students get success in learning. This also applies to the literacy activities of students at school. Self-confidence is a feeling of trust in one's abilities and environment that allows one to be open to various possible actions that are relevant to an individual (Kiverstein et al., 2019). Students need to be owned by students so that students have confidence during learning activities such as discussions, working on questions, and asking questions. Based on the results of initial observations and interviews with teachers and students at eight schools in Singkawang, it is known that most students feel insecure when conveying their opinions to teachers and when students experience problems during the learning process, students prefer to be silent and cheat on other friends' answers if they have difficulty working on the questions. Thus, referring to the results of research on reading literacy and mathematical literacy, as well as the results of initial observations about the student's selfconfidence, further research will be carried out on a description of reading literacy, mathematical literacy, and student self-confidence, and a comparative test of reading literacy, mathematical literacy, and self-confidence of students from A accredited school with B accredited school will be carried out, and comparisons between male and female students.

\section{Methodology}

This research uses quantitative research methods. According to Sugiyono (2017), quantitative research can be interpreted as a research method based on the philosophy of positivism, used to research on certain populations or samples, sampling techniques are generally carried out randomly, data collection uses research instruments, data analysis is quantitative or statistical to test the predetermined hypothesis. The type of research that will be used in this 
research is descriptive quantitative. According to Zulfah (2017), quantitative descriptive, which describes the errors made by students by using numbers.

The population in this study were all junior high school students in Singkawang. While the sample in this study was selected using the cluster sampling method. From schools with accreditation $\mathrm{A}$ and schools with accreditation $\mathrm{B}, 2$ schools were chosen. Furthermore, the sample will be grouped based on gender and student confidence level. The schools that were the sample schools in this study were SMPN 3 Singkawang, SMPN 8 Singkawang, MTs Ushuluddin Singkawang, SMPN 11 Singkawang, SMPN 17 Singkawang, Torsina Private Junior High School, and Asoka Private Junior High School. The instruments used in this study were reading literacy questions and mathematical literacy questions developed from indicators and examples

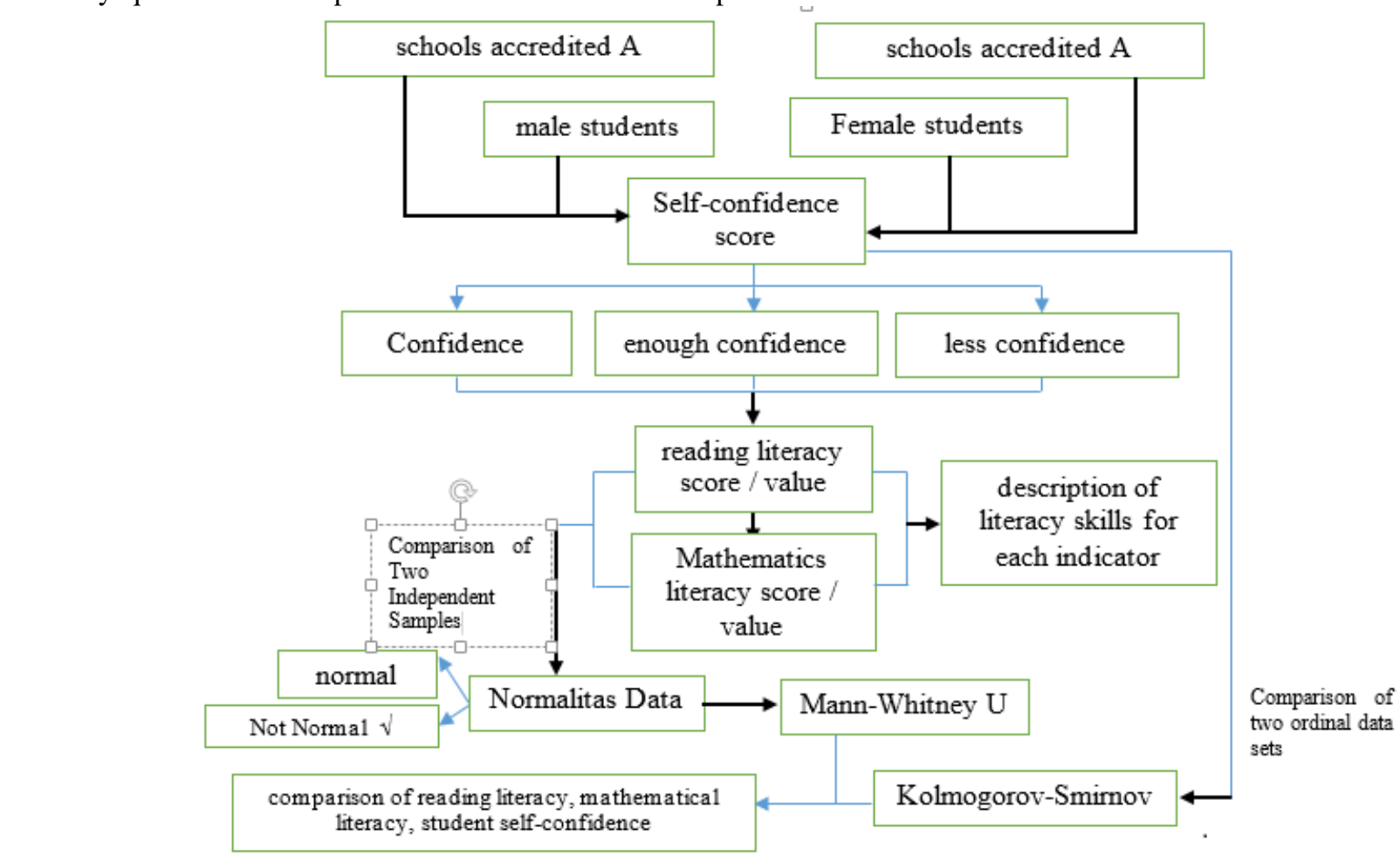

Fig. 1 Descriptive Quantitative Data Analysis Technique of existing questions, as well as student self-confidence questionnaires and interview guidelines that had previously been declared valid in content by the validator.

The objectives of this study were: (1) to describe students' reading literacy and mathematical literacy skills based on the level of self-confidence of students in schools with A and B accreditation, as well as male and female students; (2) examining the differences in reading literacy, mathematical literacy, and self-confidence between students from schools accredited A and schools accredited B, as well as male students and female students. The data analysis techniques will be explained in Fig. 1. The indicators used to compile reading literacy questions are presented in Table I. While the indicators used to compile mathematical literacy questions are based on the indicators in Table II.

TABLE I

READING LITERACY INDICATORS (SUBANDIYAH, 2017)

\begin{tabular}{lll}
\hline Language Literacy Indicator & \multicolumn{1}{c}{ Definition } & \multicolumn{1}{c}{ Indicator } \\
\hline - Gather information & $\begin{array}{l}\text { An activity carried out to obtain the } \\
\text { information needed to achieve goals through } \\
\text { reading and writing activities }\end{array}$ & $\begin{array}{l}\text { Students read the explanatory text contained in } \\
\text { the problem, then identify the structure, linguistic } \\
\text { rules, and determine the pattern of developing } \\
\text { explanatory texts } \\
\text { Students can study and write information } \\
\text { obtained from reading activities }\end{array}$ \\
- Processing information & $\begin{array}{l}\text { An activity manipulates information into } \\
\text { written form obtained from reading } \\
\text { activities } \\
\text { An ability to channel ideas, explanations, } \\
\text { feelings, statements, and questions from one } \\
\text { person to another in written form }\end{array}$ & $\begin{array}{l}\text { Students can express reasons about the structure, } \\
\text { language rules, and determine the pattern of } \\
\text { developing explanatory texts in written form }\end{array}$ \\
\hline
\end{tabular}


TABLE II

INDICATORS OF MATHEMATICAL LITERACY (OECD, 2017)

\begin{tabular}{|c|c|c|c|}
\hline No & Process & Definition & Operational \\
\hline 1 & Communication & $\begin{array}{l}\text { Read and interpret statements, questions, instructions, assignments, } \\
\text { drawings, and objects; imagine and understand the situation presented } \\
\text { and understand the information provided including the intended } \\
\text { mathematical term; present and explain one's work or mathematical } \\
\text { reasoning. }\end{array}$ & $\begin{array}{l}\text { Students can imagine and } \\
\text { understand the situation and } \\
\text { information presented }\end{array}$ \\
\hline 2 & Mathematising & $\begin{array}{l}\text { Translating extra-mathematical situations into mathematical models, } \\
\text { interpreting the results of using models related to problem situations, or } \\
\text { validating the adequacy of the model concerning problem situations. }\end{array}$ & $\begin{array}{l}\text { Students can create mathematical } \\
\text { models (make assumptions and } \\
\text { reinterpret these assumptions }\end{array}$ \\
\hline 3 & Representation & $\begin{array}{l}\text { Decoding, translating between, and utilizing mathematical } \\
\text { representations given in finding a solution; choose or arrange a } \\
\text { representation to describe the situation or to present the results of one's } \\
\text { work. }\end{array}$ & $\begin{array}{l}\text { Students can take advantage of } \\
\text { the given mathematical } \\
\text { representation to find a solution }\end{array}$ \\
\hline 4 & $\begin{array}{l}\text { Reasoning and } \\
\text { Argument }\end{array}$ & $\begin{array}{l}\text { Students can provide arguments/reasons to answer problems from } \\
\text { everyday life or mathematical problems that are following } \\
\text { mathematical concepts }\end{array}$ & $\begin{array}{l}\text { Students can provide reasons that } \\
\text { fit the concept }\end{array}$ \\
\hline 5 & $\begin{array}{l}\text { Devising Strategies } \\
\text { for Solving } \\
\text { Problems }\end{array}$ & $\begin{array}{l}\text { Select or develop mathematical strategies to solve problems and } \\
\text { monitor and control the application of strategies. }\end{array}$ & $\begin{array}{l}\text { Students can choose or develop } \\
\text { strategies to solve problems. }\end{array}$ \\
\hline 6 & $\begin{array}{l}\text { Symbols and } \\
\text { Formalism }\end{array}$ & $\begin{array}{l}\text { Understand and apply mathematical procedures and languages } \\
\text { (including symbolic expressions, arithmetic, and algebraic operations), } \\
\text { using mathematical conventions and rules that govern them; activate } \\
\text { and use knowledge about definitions, results, rules, and formal } \\
\text { systems. }\end{array}$ & $\begin{array}{l}\text { Students can understand and } \\
\text { apply concepts and procedures to } \\
\text { solve math problems. }\end{array}$ \\
\hline
\end{tabular}

\section{RESULTS AND DISCUSSION}

\section{A. Results}

The subjects in this study consisted of 168 students from 2 state junior high schools with $\mathrm{A}$ accreditation and B accreditation, as well as 1 private SMP with $\mathrm{A}$ and 2 accreditation B. Of these, 68 male students and 100 female students were also grouped. Based on the results of the analysis of the learning outcomes of 168 students, a description of the students' reading literacy and mathematical literacy abilities was obtained based on the level of self-confidence of students in schools accredited A and $\mathrm{B}$, as well as for male students and female students as shown in Table III. Meanwhile, descriptions of reading literacy and mathematical literacy based on gender are presented in Table IV.

TABLE III

DESCRIPTION OF READING LitERACY AND MATHEMATICAL LITERACY BASED ON SCHOOl ACCREDITATION AND SELF-CONFIDENCE

\begin{tabular}{|c|c|c|c|c|c|}
\hline No & $\begin{array}{c}\text { School } \\
\text { Accreditation }\end{array}$ & $\begin{array}{c}\text { Self- } \\
\text { Confidence }\end{array}$ & $\begin{array}{l}\text { \% of All } \\
\text { Subjects }\end{array}$ & $\begin{array}{c}\text { Description of Reading } \\
\text { Literacy }\end{array}$ & Description of Mathematics Literacy \\
\hline \multirow[t]{2}{*}{1} & $\begin{array}{l}\text { Accredited } \\
\text { school A }\end{array}$ & $\begin{array}{l}\text { confidence } \\
\text { (19 student) }\end{array}$ & $22.4 \%$ & 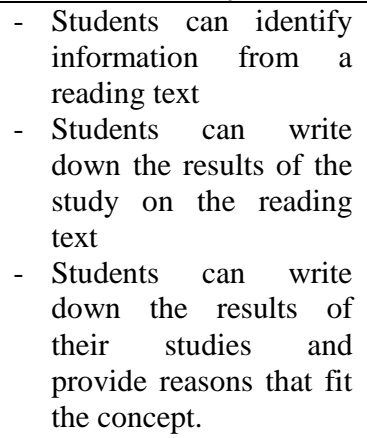 & $\begin{array}{l}\text { Students can choose or develop strategies to solve } \\
\text { problems. }\end{array}$ \\
\hline & & $\begin{array}{l}\text { quite } \\
\text { confident } \\
\text { ( } 55 \\
\text { Student) }\end{array}$ & $64.7 \%$ & $\begin{array}{l}\text { - Students have } \\
\text { identified information } \\
\text { from a reading text, but } \\
\text { there are some mistakes } \\
\text { - Students have written } \\
\text { the study results of the } \\
\text { reading text but some } \\
\text { are not following the } \\
\text { reading text } \\
\text { - Students have written }\end{array}$ & $\begin{array}{l}\text { - Students can choose or develop strategies to solve } \\
\text { problems but several strategies are inappropriate } \\
\text { or wrong. }\end{array}$ \\
\hline
\end{tabular}




\begin{tabular}{|c|c|c|c|c|c|}
\hline No & $\begin{array}{c}\text { School } \\
\text { Accreditation }\end{array}$ & $\begin{array}{c}\text { Self- } \\
\text { Confidence }\end{array}$ & $\begin{array}{l}\% \text { of All } \\
\text { Subjects }\end{array}$ & $\begin{array}{c}\text { Description of Reading } \\
\text { Literacy }\end{array}$ & Description of Mathematics Literacy \\
\hline 2 & $\begin{array}{l}\text { Accredited } \\
\text { school B }\end{array}$ & $\begin{array}{l}\text { confidence } \\
\text { (19 student) } \\
\text { quite } \\
\text { confident } \\
\text { ( } 55 \\
\text { Student) } \\
\text { Less } \\
\text { Confidence } \\
\text { (9 Student) }\end{array}$ & $\begin{array}{l}22.9 \% \\
64.7 \%\end{array}$ & $\begin{array}{l}\text { the results of their } \\
\text { studies and given } \\
\text { reasons, but several } \\
\text { reasons are not } \\
\text { according to the } \\
\text { concept. } \\
\text { - Students have } \\
\text { identified information } \\
\text { from a reading text, but } \\
\text { it is wrong } \\
\text { - Students have written } \\
\text { the results of the study } \\
\text { on the reading text but } \\
\text { it is not following the } \\
\text { reading text } \\
\text { - Students have written } \\
\text { the results of their } \\
\text { studies and provided } \\
\text { reasons, but the reasons } \\
\text { given do not match the } \\
\text { concept. } \\
\text { Students } \\
\text { identified information } \\
\text { from a reading text, but } \\
\text { there are some mistakes } \\
\text { Students have written } \\
\text { the results of their } \\
\text { studies on the reading } \\
\text { text but some are not } \\
\text { following the reading } \\
\text { text } \\
\text { Students have written } \\
\text { the results of their } \\
\text { studies and given } \\
\text { reasons, but several } \\
\text { reasons are not } \\
\text { according to the } \\
\text { concept. }\end{array}$ & $\begin{array}{l}\text { - Students cannot imagine and understand the } \\
\text { situation and information presented } \\
\text { - Students are unable to compile a mathematical } \\
\text { model (make assumptions and reinterpret the } \\
\text { arguments) } \\
\text { - Students cannot take advantage of the given } \\
\text { mathematical representation to find a solution. } \\
\text { - Students cannot give reasons that fit the concept } \\
\text { - Students cannot choose or develop strategies to } \\
\text { solve problems. } \\
\text { - Students cannot understand and apply concepts } \\
\text { and procedures to solve math problems. }\end{array}$ \\
\hline
\end{tabular}

TABLE IV

DESCRIPTION OF READING LITERACY AND MATHEMATICAL LITERACY BASED ON GENDER AND SELF-CONFIDENCE

\begin{tabular}{|c|c|c|c|c|c|}
\hline No & $\begin{array}{c}\text { School } \\
\text { Accreditation } \\
\end{array}$ & $\begin{array}{c}\text { Self- } \\
\text { Confidence }\end{array}$ & $\begin{array}{l}\% \text { of All } \\
\text { Subjects }\end{array}$ & $\begin{array}{c}\text { Description of Reading } \\
\text { Literacy }\end{array}$ & Description of Mathematics Literacy \\
\hline 1 & Male & confidence & $15.8 \%$ & $\begin{array}{l}\text { - Students have identified } \\
\text { information from a reading } \\
\text { text, but there are some } \\
\text { mistakes } \\
\text { - Students have written the } \\
\text { study results of the reading } \\
\text { text but some are not } \\
\text { following the reading texts } \\
\text { - Students have written the } \\
\text { results of their studies and } \\
\text { given reasons, but several } \\
\text { reasons are not according to } \\
\text { the concept. }\end{array}$ & 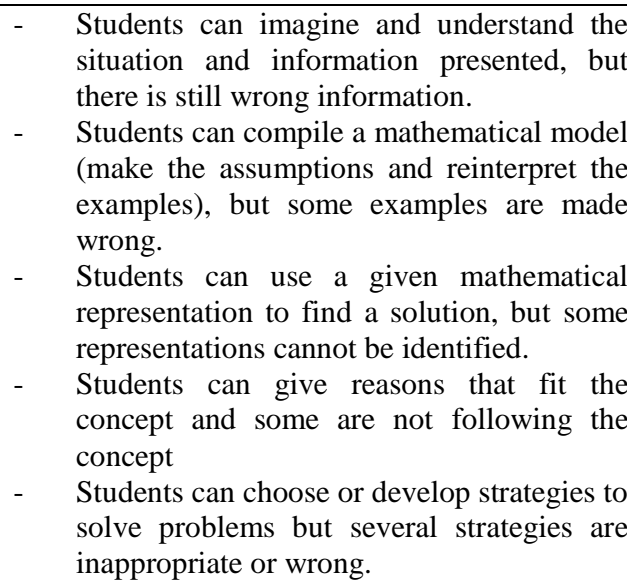 \\
\hline
\end{tabular}




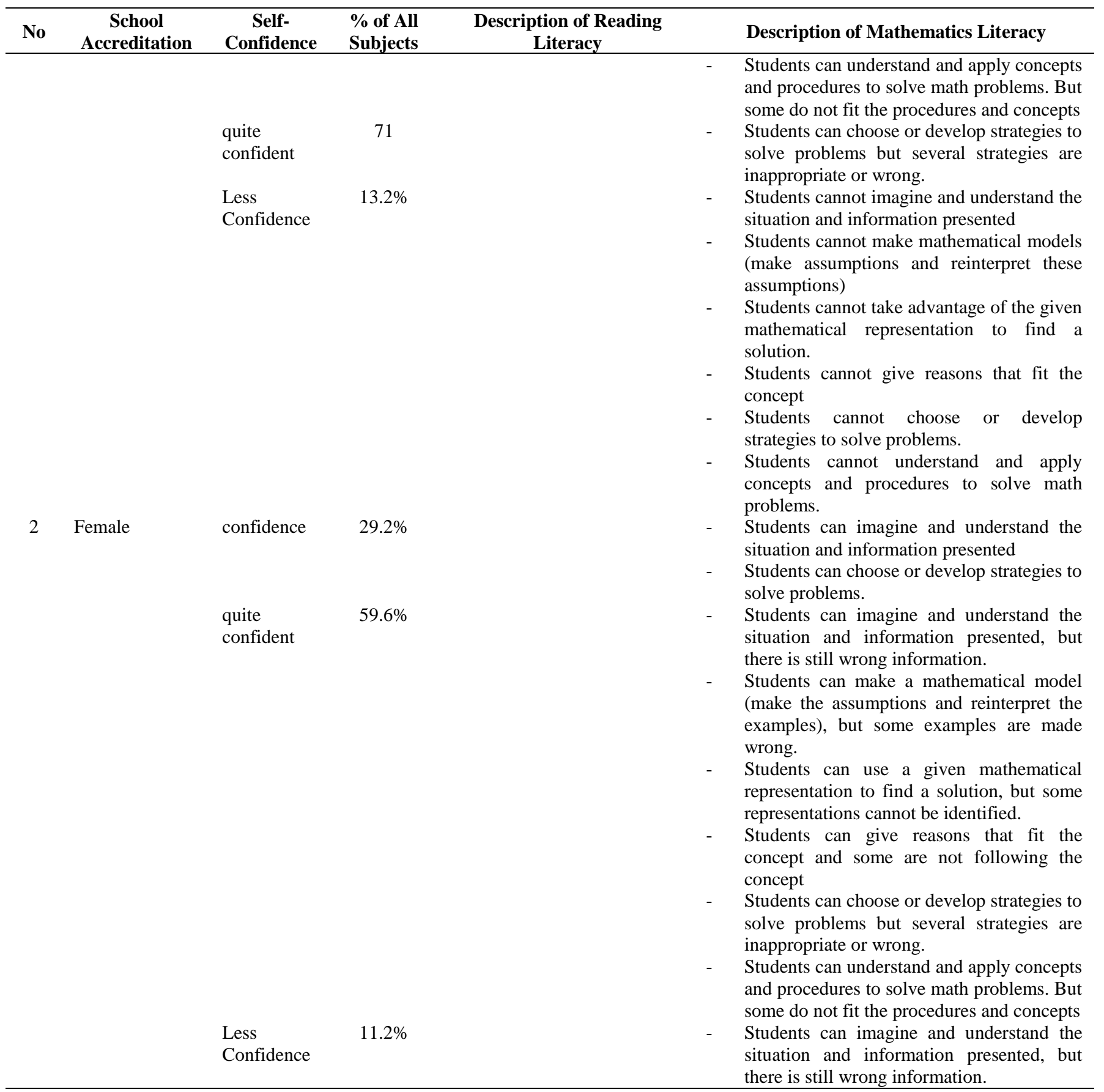

Meanwhile, to test differences in reading literacy skills, mathematical literacy, and self-confidence between students from schools accredited A and schools accredited B, as well as differences between male students and female students, the first step is taken was to test the normality of the data with the Lilifors test. Based on the results of the data normality test, data from schools accredited A, schools accredited B, male students, and female students are not normally distributed. Therefore, the distribution-free difference test or so-called non-parametric statistical test is used, namely the Mann-Whitney test for reading literacy and mathematical literacy data, and the Kolmogorov Smirnov test for student confidence data. The results of data analysis can be seen in Table $\mathrm{V}$.

TABLE V

COMPARISON OF LITERACY BETWEEN STUDENTS FROM SCHOOLS ACCREDITED A AND ACCREDITED B

\begin{tabular}{lrlr}
\hline \multicolumn{2}{c}{ Mathematics Literacy } & \multicolumn{2}{c}{ Reading Literacy } \\
\hline Mann- & 2299 & Mann- & 3029 \\
Whitney U & -3.899 & $Z$ & -1.583 \\
$Z$ & 1.96 & $Z_{\text {table }}$ & 1.96 \\
$Z_{\text {table(1-(0,05/2) }}$ & Ho rejected & Decision & $\begin{array}{l}\text { Ho accepted } \\
\text { there is no } \\
\text { Decision }\end{array}$ \\
Conclusion & there is a & Conclusion & \begin{tabular}{l} 
difference \\
\hline
\end{tabular} \\
& difference & & \\
\hline
\end{tabular}


Based on Table V, it is known that the Mann-Whitney U score for the comparison of reading literacy between students from a school accredited $\mathrm{A}$ and students from a school accredited B is 3029 . From the U value, it is obtained $Z=-1.583$. Due to the two-party comparison test, the $Z_{\text {table }}$ value is obtained from the value $\alpha=5 \%=0.05$. Because 2 parties then $\alpha=1-(0.05 / 2)=1-0.025=0.975$ so that the value of $Z_{\text {table }}=1.96$ is obtained. Ho is accepted if $-Z_{\text {Tabel }} \leq Z$ $\leq Z_{\text {table. }}$. From the analysis, it turns out that the $Z$ value is between $-Z_{\text {table }}$ and $Z_{\text {tablel }}$. This means that Ho is accepted or there is no difference in reading literacy between students from a school accredited A and students accredited B in Singkawang City. Meanwhile, for mathematical literacy between students from A-accredited schools and students from B-accredited schools, the Mann-Whitney U score was 2299. From the U score, the $Z$ score was obtained: -3.899 . Due to the two-party comparison test, the $Z_{\text {table }}$ value is obtained from the value $\alpha=5 \%=0.05$. Because 2 parties then $\alpha=1-(0.05 / 2)=1-0.025=0.975$ so that the value of $Z_{\text {table }}=1.96$ is obtained. Ho is accepted if $-Z_{\text {table }} \leq Z \leq Z_{\text {table }}$. From the analysis, it turns out that the $Z$ value is not between $-Z_{\text {table }}$ and $Z_{\text {table. }}$ This means that Ho is rejected and $\mathrm{Ha}$ is accepted or there is a difference in mathematical literacy between students from accredited A schools and students accredited B in Singkawang City. To test the differences in reading literacy and mathematical literacy based on gender, it can be seen in Table VI.

TABLE VI

COMPARISON OF Literacy BETWEEN MALE STUdENTS AND FEMALE STUDENTS

\begin{tabular}{lrlr}
\hline \multicolumn{1}{c}{ Mathematics literacy } & \multicolumn{2}{c}{ Reading literacy } \\
\hline Mann- & & Mann- & 2367 \\
Whitney U & 2302.5 & Whitney U & -3.338 \\
$Z$ & -3.546 & $Z$ & 1.96 \\
$Z_{\text {table(1-(0,05/2) }}$ & 1.96 & $Z_{\text {table }}$ & \multicolumn{1}{c}{ Ho rejected } \\
Decision & Ho rejected & Decision & $\begin{array}{l}\text { there is a } \\
\text { Conclusion }\end{array}$ \\
& there is a & Conclusion & difference \\
\hline
\end{tabular}

Based on Table VI, it is known that the Mann-Whitney U value for the comparison of reading literacy between male students and female students is 2367 . From the $U$ value, the $Z$ score is obtained $=-3.338$. Due to the two-party comparison test, the $Z_{\text {table }}$ value is obtained from the value $\alpha$ $=5 \%=0.05$. Because 2 parties then $\alpha=1-(0.05 / 2)=1-$ $0.025=0.975$ so that the value of $Z_{\text {table }}=1.96$ is obtained. Ho is accepted if $-Z_{\text {table }} \leq Z \leq Z_{\text {table. }}$. From the results of the analysis, it turns out that the $Z_{\text {count }}$ value is not between $-Z_{\text {table }}$ and $Z_{\text {table. }}$ This means that Ho is rejected and Ha is accepted or there is a difference in reading literacy between male students and female students in Singkawang City. Meanwhile, for mathematical literacy between male students and female students, the Mann-Whitney $U$ value $=2302.5$. From the $U$ value, the $Z$ value $=-3.546$. Due to the two-party comparison test, the $Z_{\text {table }}$ value is obtained from the value $\alpha$ $=5 \%=0.05$. Because 2 parties then $\alpha=1-(0.05 / 2)=1-$ $0.025=0.975$ so that the value of $Z_{\text {table }}=1.96$ is obtained. Ho is accepted if $-Z_{\text {table }} \leq Z \leq Z_{\text {table }}$. From the results of the analysis, it turns out that the $Z$ value is not between $-Z_{\text {table }}$ and $Z_{\text {table. }}$ This means that Ho is rejected and Ha is accepted or There are differences in mathematical literacy between male students and female students in Singkawang City. Furthermore, for testing differences in the level of student self-confidence based on school accreditation scores can be seen in Table VII.

TABLE VII

COMPARISON OF STUDENTS CONFIDENCE FROM SCHOOLS ACCREDITED A WITH SCHOOLS ACCREDITED B

\begin{tabular}{lr}
\hline$D_{\text {count }}$ & 0.09 \\
$D_{\text {table }}$ & 0.21 \\
Decision & Ho Accepted \\
Conclusion & there is no difference \\
\hline
\end{tabular}

Based on the results of the analysis using the two-sample Kolmogorov test whose data is ordinal in Table VII, it is known that the Kolmogorov score for the comparison of self-confidence between students from accredited schools A and students from accredited schools B, $D_{\text {count }}=0.09$ and the Kolmogorov value of the table obtained $D_{\text {table }}=0.21$. Ho is accepted if $D_{\text {count }} \leq D_{\text {table }}$. From the analysis, it turns out that the $D_{\text {count }}$ value is smaller than $D_{\text {table }}$. This means that Ho is accepted or there is no difference in the level of confidence between students from accredited A schools and students accredited B in Singkawang City. And finally, for testing the differences in students' confidence levels based on gender, it can be seen in Table VIII.

\section{TABLE VIII}

COMPARISON OF SELF-CONFIDENCE BETWEen MALE STUdENTS AND FEMALE STUDENTS

\begin{tabular}{lr}
\hline$D_{\text {count }}$ & 0.13 \\
$D_{\text {table }}$ & 0.21 \\
Decision & Ho Accepted \\
Conclusion & there is no difference \\
\hline
\end{tabular}

Based on the results of the analysis using the two-sample Kolmogorov test whose data is of the ordinal type in Table VIII, it is known that the Kolmogorov value for the comparison of self-confidence between male students and female students, $D_{\text {count }}=0.13$ and the Kolmogorov table value obtained $D_{\text {table }}=0.21$. Ho is accepted if $D_{\text {count }} \leq D_{\text {table }}$. From the analysis, it turns out that the $D_{\text {count }}$ value is smaller

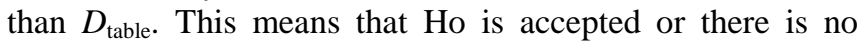
difference in the level of self-confidence between male students and female students in Singkawang City.

\section{B. Discussion}

Based on the results of the analysis, a description of the research results has been carried out about students' reading literacy and mathematical literacy ability based on student confidence levels in schools accredited A and B, as well as male and female students. 


\section{1) Description of Reading Literacy and Mathematical Literacy based on School Accreditation and Self- Confidence}

If analyzed based on the accreditation of junior high schools in Singkawang, information is obtained that schools with $\mathrm{A}$ and $\mathrm{B}$ accreditations have the same level of confidence in answering questions of reading literacy and mathematical literacy. This is also evidenced by the twosample comparison test using the Kolmogorov Smirnov test with the results that there is no difference in self-confidence between students from schools accredited A and schools with $\mathrm{B}$ accreditation. reading literacy and mathematical literacy. For reading literacy, based on a hypothesis test using the Mann-Whitney $U$, it is stated that there is no difference in reading literacy skills between students from accredited schools A and B. This is following the statement in previous research which states that school accreditation is not a benchmark for determining a height or low effective quality and school quality (Mongi \& Hatidja, 2016; Setiyaningsih, 2017; Multahadah, 2018). But if viewed based on the level of self-confidence of students, students with a level of trust High self-esteem in schools accredited A has been able to apply all indicators of reading literacy, for students who are confident enough to be able to carry out all indicators of reading literacy even though they still make mistakes, and for less confident students they have implemented all indicators even though they are not according to orders or does not fit the concept. For confident students, quite confident and lacking confidence from schools accredited B has been able to implement all indicators of reading literacy, but most of them still make some mistakes such as some answers that do not match the concept.

For mathematical literacy, based on the two-sample comparison test using the Mann-Whitney $\mathrm{U}$, it was concluded that there were differences in mathematical literacy abilities between students from A and B accredited schools. Based on the average value, students from accredited B schools were higher than the average value of students from schools with accreditation A. This is following the previous opinion which states that school accreditation cannot be used as a benchmark for determining the level of student learning effectiveness. After further analysis, information was obtained that 3 out of 4 schools that have B accreditation have an environment that matches the literacy question given. while schools that were accredited A were all located in urban environments far from hilly areas. The environment of the B accredited school is the hilly area behind the school and the student's residence. The mathematical literacy problem given is following the theme of the school environment and student residence so that it is more realistic. This is supported by the research results of Sumirattana, Makanong, and Thipkong (2017) which stated that the group of students in Bangkok, Thailand who are taught with Realistic mathematics is significantly higher than taught through conventional learning. Another opinion also states that almost $63.17 \%$ of the differences in students' math literacy scores are caused by differences between schools. The influence of variables such as gender, school type on mathematics literacy in schools was found to be statistically significant (Aksu, Güzeller, \& Eser, 2017).

The results of the analysis based on indicators of mathematical literacy skills show that students who are confident in schools with A accreditation can implement Devising Strategies for Solving Problems indicators and for other indicators, namely Communication, Mathematising, Representation, Reasoning and Argument and Symbols, and Formalism can be implemented, but there are still results and processes that are wrong or not following mathematical concepts. For students who are confident enough, students are only able to carry out the Devising Strategies for Solving Problems process but there are still errors or not according to the concept. And students who lack confidence, cannot carry out the mathematical literacy process. For students who are confident and confident enough in schools with B accreditation, they can apply the Devising Strategies for Solving Problems process, and for other processes, they still make some mistakes. For students who lack self-confidence, the description is the same as students from an A-accredited school.

\section{2) Description of Reading Literacy and Mathematical Literacy based on Gender and Self-Confidence}

If analyzed based on gender, there is no difference in the level of confidence between students from schools with A and B accreditation at SMP Kota Singkawang, this is evidenced by the results of the hypothesis test using the Kolmogorov Smirnov test. But if it is related to students' reading literacy and mathematical literacy, based on the hypothesis test using the Mann-Whitney $\mathrm{U}$, it is concluded that there are differences in reading literacy and mathematical literacy skills between male students and female students. From the average score of students, it is known that the literacy skills of female students are better than male students. For reading literacy, female students are superior to male students in line with the results of research conducted by Dong and $\mathrm{Hu}$ (2019) and Sumirattana, Makanong, and Thipkong (2017) who stated that gender is the main indicator that affects students' reading performance. Gender differences can affect education outcomes and reading literacy. Female students performed better than boys in the PISA study. Whereas for mathematical literacy the research results are not in line with the findings of PISA which stated that male students' mathematical abilities are better than female students in terms of PISA exams (OECD, 2017). However, according to the OECD (2014) and Ana (2018), this difference in ability depends on the environment in which students live because some countries that take the PISA exam show the opposite. According to Egorova (2016), students' mathematical literacy skills depend on the context of measurement and the student's learning period. According to Egorova, female students excel in mathematics during adolescence, while male students will excel in mathematics when they enter college. When viewed from the measurement point of view during the learning period, 
female students are superior, while in taking certain tests, male students are superior to female students.

For reading literacy descriptions students who are confident, confident enough and not confident, each indicator has been able to identify information from a reading text, but there are some mistakes, have written the results of the study of the reading text but there are some that are not appropriate with the reading text and have been able to write down the results of the study and provide reasons for it, but there are several reasons given that are not following the concept. The difference is those female students are more detailed in writing answers than male students. For the description of mathematical literacy, male students who are confident can carry out all mathematical literacy processes, but still, make some mistakes or are not following mathematical concepts. Students who are confident enough are only able to carry out the Devising Strategies for Solving Problems process but there are still errors or not following the concept. And students who lack self-confidence cannot carry out all mathematical literacy processes. for female students who are confident that they can carry out the Communication and Devising Strategies for Solving Problems processes. Meanwhile, other processes still make some mistakes. For students who are confident enough to have carried out all the mathematical literacy processes even though they still make some mistakes. For less confident students, they can implement the Devising Strategies for Solving Problems process even though they still make some mistakes, and for other processes, it cannot be implemented.

\section{CONCLUSIONS}

The conclusions in this study for the description of students' reading literacy and mathematical literacy are (a) for schools with A accreditation, only confident students can process Gather information, Processing information, and Communicating information on reading literacy, while for mathematical literacy students who are confident are only able to carry out the process of indicators for Devising Strategies for Solving Problems. For schools with B accreditation, students who are confident, confident enough, and less confident have carried out all the reading literacy process, but there are still some errors in the workmanship and not following the concept, while for mathematical literacy, students who are confident and confident enough only able to carry out the Devising Strategies for Solving Problems indicator process. (b) For male students and female students who are confident, confident enough, and less confident that they have carried out the process of gathering information, processing information, and communicating information on reading literacy but still making some mistakes and not according to the concept. As for mathematical literacy, only female students who are confident can carry out the Communication and Devising Strategies for Solving Problem processes.

For the comparative test of reading literacy, mathematical literacy, and student self-confidence, namely: (a) there is no difference in reading literacy between students from schools accredited A and B. (b) There are differences in mathematical literacy differences between students from accredited schools A and B. (c) There are differences in reading literacy and mathematical literacy between male students and female students. (d) There is no level of student confidence based on school accreditation and gender.

\section{ACKNOWLEDGMENT}

We would like to thank Ristekdikti who has funded this research and the 10 STKIP Semester 5 students of the 2019/2020 academic year who have helped in collecting student confidence data by conducting interviews with students.

\section{REFERENCES}

Aksu, G., Güzeller, C. O., \& Eser, M. T. (2017). Analysis of maths literacy performances of students with Hierarchical Linear Modeling (HLM): The Case of PISA 2012 Turkey. Egitim ve Bilim, 42(191).

Ana, O. (2018). PISA 2012 mathematics literacy in Serbia: A multilevel analysis of students and schools. Psihologija, 51(4).

Asmara, A. S., Waluya, S. B., \& Rochmad, R. (2017). Analysis of Mathematics Literacy Based on Mathematical Ability. Scholaria: Jurnal Pendidikan Dan Kebudayaan, 7(2), 135-142.

Collins, J. (1995). Literacy and literacies. Annual review of anthropology, 24(1), 75-93.

Delgadova, E. (2015). Reading Literacy as One of the Most Significant Academic Competencies for the University Students. Procedia - Social and Behavioral Sciences, 178, 48-178.

Dong, X., \& Hu, J. (2019). An exploration of impact factors influencing students' reading literacy in Singapore with machine learning approaches. International Journal of English Linguistics, 9(5).

Egorova, M. S. (2016). Sex differences in mathematical achievement: Grades, national test, and selfconfidence. Psychology in Russia, 9(3), 4.

Fleischman, H. L., Hopstock, P. J., Pelczar, M. P., \& Shelley, B. E. (2010). Highlights from PISA 2009: Performance of US 15-Year-Old Students in Reading, Mathematics, and Science Literacy in an International Context. NCES 2011-004. National Center for Education Statistics.

Frankel, K. K., Becker, B. L., Rowe, M. W., \& Pearson, P. D. (2016). From "what is reading?" to what is literacy?. Journal of Education, 196(3), 7-17.

Gee, J. P. (1998). What is literacy? Negotiating academic literacies: Teaching and learning across languages and cultures, 51-59.

Hayati, T. R., \& Kamid, K. (2019). Analysis of Mathematical Literacy Processes in High School Students. International Journal of Trends in Mathematics Education Research, 2(3), 116-119.

Hidayat, Y. N., Wardono, W., \& Rusilowati, A. (2019). Analysis of Mathematics Literacy Ability Observed 
from Metacognition in Learning Realistic Synectics Assisted by Schoology. Unnes Journal of Mathematics Education Research, 41-47.

Kalantzis, M., Cope, B., Chan, E., \& Dalley-Trim, L. (2016). Literacies. Cambridge University Press.

Kastberg, D., Chan, J. Y., \& Murray, G. (2016). Performance of US 15-Year-Old Students in Science, Reading, and Mathematics Literacy in an International Context: First Look at PISA 2015. NCES 2017-048. National Center for Education Statistics.

Kiverstein, J., Rietveld, E., Slagter, H.a., \& Denys, D. (2019). Obsessive Compulsive Disorder: A Pathology of Self-Confidence?. Trends in Cognitive Sciences, 23(5), 369-372.

Ma, X. (2008). Within-school gender gaps in reading, mathematics, and science literacy. Comparative Education Review, 52(3), 437-460.

Mongi, C. E., \& Hatidja, D. (2016). Perbandingan SMA Negeri Dan SMA Swasta Berdasarkan Nilai Akreditasi dan Nilai Ujian Nasional Menggunakan Uji-T di Kota Manado. Jurnal Ilmiah Sains, 16(2), 91-97.

Multahadah, C. (2018). Analisis Klasifikasi Akreditasi $\mathrm{Sma} / \mathrm{ma}$ Berdasarkan Faktor-faktor yang Mempengaruhi Se Provinsi Jambi dengan Rltog. EKSAKTA: Berkala Ilmiah Bidang MIPA, 19(1), 113-117.

OECD. (2017). How does PISA for development measure mathematical literacy? PISA for Development Brief, I. (Agustus 2020), 0-1. https://doi.org/10.1787/9789264208780-en

Setiyaningsih, C. D. (2017). Status Akreditasi dan Kualitas Sekolah di Sekolah Dasar Negeri. JMSP (Jurnal Manajemen dan Supervisi Pendidikan), 1(2), 138145.

She, H. C., Stacey, K., \& Schmidt, W. H. (2018). Science and mathematics literacy: PISA for better school education. International Journal of Science and Mathematics Education, 16(1), 1-5.

Shu-Hua, T. (2017). Design student-centered textbooks to enhance the reading literacy of young people. Jiaoke Shu Yanjiu: Journal of Textbook Research, 10(2), 1.

Sugiyono. (2017). Metode Penelitian Kuantitatif, Kualitatif dan R\&D. Bandung: Alfabeta.

United Nations Educational, Scientific and Cultural Organization (UNESCO) (2013) Literacy Policy. Available at: www.unesco.org/new/en/education/themes/educatio n-building-blocks/literacy/ (Accessed 21.07.2020).

Wildová, R. (2015). Monitoring the Use of Innovative Psycho-didactic Processes in Reading Literacy Development. Procedia - Social and Behavioral Sciences, 171, 60-65.

Y1lmazer, G., \& Masal, M. (2014). The Relationship between Secondary School Students' Arithmetic Performance and their Mathematical Literacy.
Procedia - Social and Behavioral Sciences, 152, (619-623).

Zulfah. (2017). Analisis Kesalahan Peserta Didik Pada Materi Persamaan Linier Dua Variabel di Kelas VIII MTs Negeri Sungai Tonang. Jurnal Cendikiawan: Jurnal Pendidikan Matematika, 1(1), 12-16. 